AperTO - Archivio Istituzionale Open Access dell'Università di Torino

\title{
Experimenting with professional innovation through practice learning
}

\section{This is the author's manuscript}

Original Citation:

\section{Availability:}

This version is available http://hdl.handle.net/2318/1675609

since 2018-08-31T13:15:28Z

Published version:

DOI:10.1080/13691457.2018.1513396

Terms of use:

Open Access

Anyone can freely access the full text of works made available as "Open Access". Works made available under a Creative Commons license can be used according to the terms and conditions of said license. Use of all other works requires consent of the right holder (author or publisher) if not exempted from copyright protection by the applicable law. 
EUROPEAN JOURNAL OF SOCIAL WORK

https://doi.org/10.1080/13691457.2018.1513396

\title{
Experimenting with professional innovation through practice learning Sperimentare l'innovazione professionale attraverso il tirocinio
}

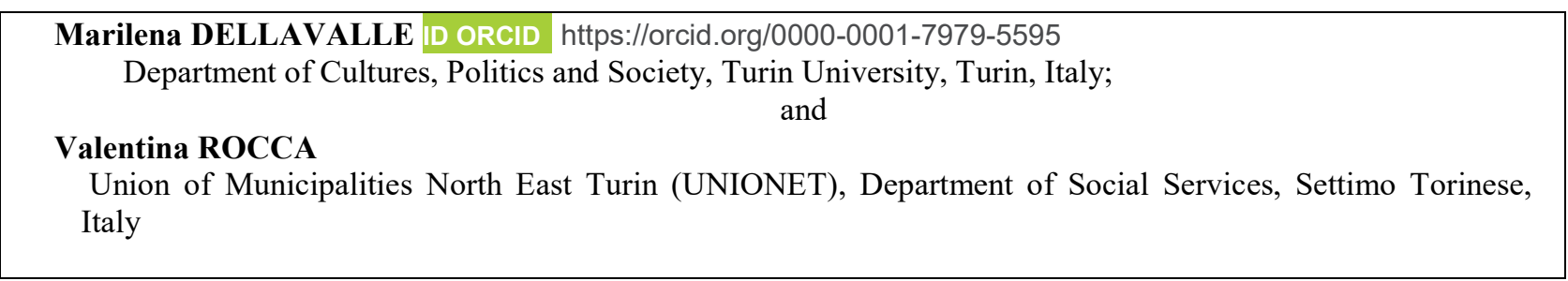

ISSN: 1369-1457 (Print) 1468-2664 (Online) Journal homepage: http://www.tandfonline.com/loi/cesw20

This is an Accepted Manuscript of an article published by Taylor \& Francis in European Journal of Social Work on August 23, 2018 available online: https://www.tandfonline.com/doi/full/10.1080/13691457.2018.1513396

Questo è il manoscritto accettato dell'articolo pubblicato da Taylor \& Francis Group in European Journal of Social Work il 23 agosto 2018, disponibile online a questo link:

https://www.tandfonline.com/doi/full/10.1080/13691457.2018.1513396

\begin{abstract}
This paper presents a qualitative study of an experimental project carried out by the Bachelor of Social Work programme at the Università di Torino (Italy) to promote new opportunities for employment in a welfare system that has been affected by the global crisis. The project organised practice learning placements at 15 non-profit agencies where social workers are not normally part of the staff.

A review of the international literature indicates that interest in such initiatives is not restricted to Italy. The study employed semi-structured interviews and focus groups involving students, supervisors, tutors and agency contacts. The study's findings bear out the value of experimental practice learning in two main areas: promoting the social work profession - the experimental placements helped disseminate a favorable view of the profession, and in some cases resulted in social workers being hired by the agencies concerned; training - the experimental placements stimulated students' ability to learn proactively, through exploration and questioning. It was found that there is a need to provide the students involved in the placement with greater support to ensure that they do not regard the experience as being less useful than conventional placements where participants can observe practitioners in action.
\end{abstract}

\section{SOMMARIO}

Il contributo presenta i risultati di una ricerca relativa a un progetto sperimentale del Corso di Laurea di Servizio Sociale dell'Università di Torino (Italia) finalizzato a promuovere nuovi spazi professionali all'interno di un welfare investito dagli effetti della crisi globale. La sperimentazione ha riguardato la realizzazione di 65 tirocini in 15 organizzazioni del Terzo settore, dove tradizionalmente non è presente la figura dell'assistente sociale.

Dalla rassegna della letteratura internazionale emerge un interesse per questo tema, non limitato alla realtà italiana. Nella ricerca, condotta con metodologia qualitativa, sono stati 
utilizzati l'intervista semi strutturata e il focus group e sono stati coinvolti studenti, supervisori, tutor, referenti dei servizi. I risultati testimoniano la validità del tirocinio sperimentale, su due versanti: la promozione del servizio sociale - le esperienze hanno contribuito a diffondere visioni corrette della professione e, in alcuni casi, ancorché limitati, hanno condotto all'introduzione della figura dell'assistente sociale all'interno dell'ente; la formazione - il tirocinio sperimentale si è rivelato in grado di sollecitare la capacità di apprendere in modo attivo,

\section{KEYWORDS}

Social work education; practice learning; innovation; experimentation

PAROLE CHIAVE

Servizio sociale; formazione; tirocinio; innovazione; sperimentazione (c) 2018

\section{Introduction}

Practice learning or field education - as a process of learning from experience is universally recognized as a key curriculum component in social work programs (Rehn \& Kalman, 2016; Domakin, 2015; Tognetti Bordogna 2015; Gursansky, Le Sueur, 2012). Collaboration between social service agencies and academic institutions is regarded as essential in improving the quality of education, and there is equal agreement on the need to guide the student in integrating practice and theory (Wilson, 2014; Wilson, Kelly, 2010; Clapton et al., 2006; Noble, 2001).

The ongoing global crisis has affected the Italian welfare system, resulting in fewer resources and the managerialisation of social services (Bertotti, 2015). This has led to a loss of job prospects in the areas where social workers have traditionally been employed, while new openings are appearing on the non-profit scene (Tognetti Bordogna, 2015; Fazzi, 2012). One of the emerging needs would thus seem to be that of finding new horizons that the profession can move into without losing its identity (Scholar, McLaughlin, McCaughan, \& Coleman, 2014).

University social work education programs can promote forms of experimentation in professional practice in a number of as-yet-unexplored areas through experimental practice learning (EPL) in settings where there are no social work practitioners but where it is thought they could make significant contributions.

This paper presents a study of EPL conducted in 2005-2013 by the Bachelor of Social Work program at the University of Torino (Italy) with 65 students and 15 nonprofit organizations. The study investigated EPL's effectiveness as an educational experience and its ability to generate professional innovation. 
After presenting the project and research method, we will illustrate our main findings regarding EPL's educational outcomes and ability to open up new opportunities for the social work profession.

\section{Collaboration between universities, the profession and agencies}

Practice learning is one of the major arenas where the relationships between producers of social services, the professional community and educational institutions are played out: it is here that the interdependence between theory and practice comes to life (Lewis, Kusmaul, Elze \& Butler, 2016). Practice learning can trigger interchanges that can benefit agencies and practitioners as well as degree programs. The university can bring together the current and dynamic components of that vital world for which future social workers must be trained. At the same time, the professional community can provide more extensive opportunities for discussion and cultural stimulus than the often constricted life in the agencies is likely to offer.

For the agencies, hosting practice learning programs means deploying resources for education, but it also means recognizing their own significance and bringing the quality of their work to the outside world's attention. The relationship with the university, moreover, is an opportunity for cross-fertilization with the world of research and theory production, from which another world - that of the social services - can draw valuable insights and impetus that can also be built on in conducting innovative interorganizational projects.

Gursansky \& Le Seur (2012, p. 2014) describe field education as a "sacred cow" of social work, but call for closer scrutiny of certain weaknesses stemming from the low status that academic social work programs accord to learning practice skills, and the fact that it is not easy for universities to find practice learning placements that are reliable from the educational standpoint (Domakin, 2015). The problems that are mentioned in this connection include host organizations' reluctance to accept students or to allow social workers to devote the necessary time to students (Crisp \& Hosken, 2016).

Supervision is considered to be an essential part of field education, as noted by van Hees \& Geißler-Piltz (2010), but it is not always possible to guarantee its quality. One of the first problems is that social workers have a heavy workload, which is rarely 
reduced when they assume supervision responsibilities in addition to their other duties (Gursansky \& Le Sueur, 2012). Another difficulty mentioned by Hubbard \& Kitchin (2010) is that universities can take supervision for granted, and consequently - as Domakin (2015) observes - they devote little attention to interacting with the social workers who take on practice educator roles.

Crisp \& Hosken (2016) state that the need to increase the number of student placements has led universities to explore alternative types of field work in organizations where there are no social workers, and staff from other professions act as supervisors. Such situations, which had been reported earlier by Bellinger (2010), risk reducing learning opportunities in the core area of social work and can hamper the process of professional identification, which is not free from difficulties even for those students in conventional placements (Fargion, 2008).

These problems are compounded by the global crisis, austerity policies (Garrett \& Bertotti 2016) and managerialism, whose effects include a curtailment of the resources channeled into the welfare system and dimmer prospects of steady employment for social workers, which have also impacted educational processes (Morley \& Dunstan, 2013).

In such a context, cooperation between universities, the professional community and field agencies is more important than ever before, not least in order to guarantee appropriate learning opportunities. There has always been a need for a solid alliance between all the actors involved, as was pointed out by Bogo \& Globerman (1995) and confirmed by Clapton et al. (2006), whose study emphasizes the importance of this synergy, which is useful not only for students but also for integrating learning in practice and vice versa.

\section{The experimental project's objectives and setting}

In Italy, a number of different processes have impacted education programs for social workers, and practice learning in particular. On the one hand, the sweeping changes made in university degree programs at the beginning of this century resulted in a massive increase in enrollment (Facchini, 2010) and thus a need for more student placements, which have traditionally been made in the public field agencies that are the chief employers of Italy's social workers. 
The burgeoning non-profit sector, on the other hand, has not absorbed large numbers of social workers, despite its compatibility in terms of skills and functions (Fazzi, 2012). The professional community has considered employment in the nonprofit sector to be second-best to working in public agencies (Fazzi, 2012).

As early as 2005, the Università di Torino Bachelor of Social Work (BSW) program embarked on an experimental project for practice learning in third sector organizations which do not yet have social workers on site. In addition to guaranteeing the educational content needed for professionalization, the experimental project also set out to explore uncharted waters, adopting a flexible and creative approach which is appropriate for a work environment that has changed so much, and so recently. The non-profit sector proved to be particularly interesting because of its capacity to provide social work with new opportunities and occasions to express its potential (Fazzi, 2012).

In the following years, public funding cuts (Garrett \& Bertotti, 2016) and the concurrent proliferation of third sector organizations have increased the need to find new opportunities for practitioners (Tognetti Bordogna, 2015).

It should be borne in mind that in the 1950s and ' $60 \mathrm{~s}$, Italy's schools of social work promoted the spread of the profession into areas it had not previously entered, paving the way to such important arenas of action as school, hospital and community social work (Dellavalle, 2011).

One of the most noteworthy features of the experimental practice learning project is that the student is placed in an organization where there are no social workers. In "classic" practice learning placements, by contrast, the student accompanies the social worker in services where the professional role is defined and recognized, and where supervision is provided by the practitioner. In the experimental practice learning project, on the other hand, supervision is provided by a social worker external to the host agency, who is designated and paid by the university, and for that reason is said to be "delegated". The delegated supervisor is selected on the basis of an open call for candidates who can demonstrate that they have accredited experience in practice learning supervision and specific expertise in the area in which the host organization operates.

In both types of practice learning placement, the university takes responsibility for guiding the process of interpreting the experience in the light of theory, using a variety of means (Dellavalle, 2014). The learning experience is monitored by the tutor, 
a social worker who and acts as a liaison between the degree program and the agencies. The tutor must ensure that the placement proceeds as agreed, without going off course: though retaining a certain flexibility, the intended learning outcomes cannot be impeded or replaced, and the student must be provided with professional content.

As the students cannot benefit from direct observation of how a practitioner operates, they must have a pronounced ability to picture the role (Dellavalle, 2011), an ability to proceed with a high degree of independence, and a critical, reflexive attitude whereby they can integrate the professional and personal selves (Marlowe et. al, 2015; Man Lam, Wong \& Tse Fong Leung, 2006). Accordingly, the university selects the students admitted to the experimental project on the basis of certain specific characteristics, including a high level of self-sufficiency and excellent theoretical grounding.

\section{The investigation}

Qualitative methods were used to investigate two aspects: the project's outcomes in terms of the students' acquisition of professional skills; and the impact that accepting students on practice learning placements and cooperating with the university had on the host organizations.

To pursue these goals, the investigation was divided into three specific stages. The first stage consisted of a review of the literature found by searching the Scopus citation database using the keywords social work, field education, placement, practice learning, integration theory and practice, relationships cooperation, non traditional, innovation, crisis. This review made it possible to analyze the project in the light of the theoretical literature on the practice learning process, the relationship between universities, the professional community and field agencies, the obstacles to quality supervision and the alternatives to conventional placements.

The second stage consisted of an examination of student records ${ }^{1}$ in order to collect empirical data on the project and its protagonists.

1 Transcripts issued by the Bachelor of Social Work program provided the following information for each of the students involved in the project: age, gender, first year of enrolment, pre-university education, grade point average prior to practice learning placement, program year 
The third stage centered on active exchanges with participants who had been involved in the entire period covered by the project, viz., seven out of the ten supervisors, three of the four tutors and six of the fifteen host organization contacts. Semi-structured in-depth interviews were conducted with these participants and then transcribed verbatim.

Of the 65 students involved in the entire course of the EPL project, only 11 belonging to different cohorts participated in the study ${ }^{2}$. For these students, empirical data was collected by means of focus groups (Wibeck, Abrandt Dahlgren \& Öberg, 2007). Discussion was encouraged by providing images and metaphors for describing the placement, and which leave space for the imagination while evoking emotional responses and memories of past experience.

The entire study complied with all ethics requirements applying in Italy, and in particular with the confidentiality requirements contemplated by current legislation and the Italian National Research Council Guidelines on Research Integrity (CNR, 2015), taking care not to suppress or misrepresent unsatisfactory or inconvenient findings.

\section{Findings}

Examining the data contained in student records made it possible to sketch a profile of the project participants.

Overall, the EPL project involved 65 students in experimental practice-learning placements that accounted for $7 \%$ of the 940 placements that took place during the period, and ranged from a minimum of 2\% in Autumn 2008 to 16\% in Spring 2005.

The university provided 11 delegated supervisors and 4 tutors, all of whom were social workers specializing in this type of practice learning.

The 15 non-profit organizations involved in the project are agencies that manage services in different areas, including support in cases of socioeconomic disadvantage, child welfare and family services, mental illness, substance abuse, disability, protection of unaccompanied foreign minors and victims of violence in general, sexual

in which practice learning took place, practice learning evaluation, final assessment, host organization, tutor and delegated supervisor.

${ }^{2}$ Of the 65 former students who were contacted, 18 did not respond, 16 indicated that they were unable to participate in the study, 31 expressed an interest but only 11 actually participated, as the others were prevented from doing so by work or family commitments. 
exploitation, human trafficking, social inclusion and labor market integration of disadvantaged people, and gerontological social work. It should be noted that over half $(56 \%)$ of the students were hosted by only two agencies, while the remaining $44 \%$ were placed in one of the other thirteen agencies which cooperated with the university at that time.

A few words are also in order concerning the type of student who was involved: the portrait that emerged from the study was compared with the admissions criteria used by the tutors to determine whether there were any connections with the project's outcomes. It was found that students participating in the experimental project tend to be older when they begin their practice learning placements than students in a regular academic career: the students in "classic" placements are an average of 26.7 years old, an age exceeded by $29 \%$ of the EPL students.

As regards scholastic achievement, the participants' grade point average prior to the start of the EPL is proof of their brilliant academic career, though it should also be borne in mind that the BSW program selects the students to be admitted to the experimental project from among those who have the most solid educational background and show the greatest independence. The grade assigned to these students' final report ${ }^{3}$ is particularly significant, averaging 27.6 out of 30 . This is especially high by comparison with the average grade achieved by their compeers in the traditional programs (and thus assigned by the same examination committee), which is 23.5 out of 30. In this connection, though it should once again be borne in mind that the participants started from a position of advantage, it is also true that the experimental project puts greater demands on the student's self-sufficiency and requires them to make a greater effort to picture what their role should be.

Can EPL guarantee educational quality, even though it takes place at sites with no social workers? To answer this question, we considered the student profiles discussed above, and analyzed the statements made by interviewees on two issues: delegated supervision, and the experimental placements' educational potential.

3 The final report, which the student prepares on the basis of a template provided by the university, is taken into consideration in the overall evaluation of the placement. In the report, the student discusses the practice learning experience, and must provide explicit theoretical justification for the arguments advanced. 
As the documentation ${ }^{4}$ produced by the study indicates, there was a general consensus among all interviewees regarding the first issue, while field educators and students differ in their views of the second, as we will see below.

\subsection{Delegated supervision}

Mentoring on the part of the supervisor was judged favorably by all groups of interviewees. Supervisors and tutors maintain that this contribution guarantees the educational nature of the experience, ensuring that what happens in the placement is reflected on and internalized, and that links can be forged between practical experience and theoretical knowledge.

Contrary to what might be expected, the fact that the supervisor is not part of the agency and has only sporadic contacts with the student does not make the supervision any less valuable. Indeed, all of the interviewees rated delegated supervision positively, as it is assigned well defined spaces and times, far from the hectic rush of an agency's everyday life. This increases delegated supervision's added value, even by comparison with traditional supervision, where unfortunately it is not always possible to have much control over the setting because of excessive workloads and the need to respond to urgent situations as they arise.

Some of the field educators we interviewed also acknowledge that meeting with the supervisor at scheduled times and in specific places encourages students to try to reflect on their own about what they have done before the supervision session. The reference here is to the ideas advanced by Dewey (1910), i.e., that reflexive thinking can be promoted when the person who is being trained is encouraged not to seek immediate answers, but to take the trouble to think about the action and discuss it in the supervision session, where "[...] the material that the student brings is taken apart and put back together", as one supervisor remarked (SV07). This can encourage reflexive learning in later practice (Man Lam, Wong \& Tse Fong Leung, 2007), where reflexivity is one of the professional skills (Schön, 1993) of a practitioner who is capable of "[...] knowing-in-action, reflection-on-action and reflection-in-action” (Sicora, 2010, p. 20).

\footnotetext{
${ }^{4}$ This documentation consists of the 65 students' reports and full transcriptions of the focus groups and the interviews with supervisors, tutors and agency contacts.
} 
Several analogies with studies of international learning placements such as that carried out by Askeland et al. (2016) also came to light. Two stand out in particular:

- The use of the metaphors of transmission and participation. The former presupposes passive transmission of consolidated knowledge from an expert to a learner, while the learner expects to participate actively in his learning processes and in the creation of knowledge.

- The centrality of reflexivity to practice learning.

The students we interviewed recognized that the supervisor mentored them in pursuing two goals: first, connecting the experience to the theoretical basis and specificity of social work, and second, reflecting on the experience from the standpoint of the insights and feelings arising from the placement. The students, like the educators, do not consider the fact that the supervisor does not belong to the agency as an obstacle to establishing a learning relationship or 'working alliance' (Fazzi \& Rosignoli, 2014) based on reciprocal trust; indeed, the latter is seen as a central factor in the relationship created between the two parties.

Working with the images given to the students as stimulus material during the focus groups shed light on how the practice learners saw their supervisor as a figure who was particularly close to them in their journey. Only two of the young women reported feeling a sense of solitude during the placement, while the majority associated the educator with photographs evoking the idea of a solid support. For one of the students, the most appropriate image is that of the figure at the end of the tunnel, because "my supervisor accompanies me and helps me find my way. I'm sure that if I hadn't been open with him, my placement wouldn't have been the positive experience it turned out to be, precisely because it was thanks to him that I was able to face the first moment of difficulty" (S11).

From the supervisor's standpoint, the quality of the relationship of trust established with the student provides an opportunity to transform his condition from being a stranger to the placement setting to being simply outside it: through the student's eyes, the supervisor can come to know the setting; through the student, he enters the agency, observes and understands.

Creating a relationship of trust is essential in making it legitimate for students to talk about what happens to them day by day, without feeling judged or evaluated. It is 
important that students perceive the trust that the supervisor places in them, because they will thus be able to return to the agency after the supervision period and put their own abilities to use in dealing with the many tasks that are thrown their way. This function, which we might call promotional, emerges from the words of one of the interviewed supervisors:

[...] there's a part of the relationship that's even quite moving, when it helps these students mature [...] this question of letting them go ahead and having trust because the student will go back to a context where she'll have to manage on her own and will have to take control of her own tasks, because maybe she'll realize that things are being asked of her that maybe are out of line, and so she'll have to find the way, the words, the tools for standing up for herself, building her own setting not only in the relationship with clients, but also in the professional relationship, and thus find her own role, her own space. This is accentuated, not that it doesn't happen in a classic practice learning placement (SV07).

\subsection{Educational potential}

The study's findings confirmed that this practice learning model can promote the acquisition of professional skills in a context where no practitioners are present. The strong points mentioned by the educators include the centrality of the nexus between theory and practice, and the opportunity to test a non-imitative learning model.

Unfortunately, the students showed that they did not fully understand the innovative significance of their experience, even when they stated that they were satisfied. One of the most critical aspects is the perception that the university shows "little recognition" of their difficulties and achievements in the experimental placement. The first risk this entails is that the supervisors and other mentors will not be able to help students bring the placement's positive features into focus and understand the added value it provided. Some of the interviewed students seem to harbor the suspicion that EPL is simply a cover for the need to find placements for large numbers of students.

\subsection{The theory/practice nexus}

Whereas students in a traditional placement can have immediate access to professional tools and content, trainees in the experimental project must seek them in a hybrid context, taking action themselves, as one of the young women observed: "I feel that I'm laying out my own route" (S13). The experimental placement kindles an 
attitude of discovery and reflection that can be a valuable asset to the students during their traineeship, and also stand them in good stead in their future professional activity. This is an approach informed by transformative learning theory (Mezirow, 1991), as the experience, and especially the reflection on it, can lead to a transformation of the initial perspective, enriching and adding to the students' meaning schemes. During the supervision session, as one educator stated, "[...] we take the role, the professionalism, the professional ability and we fan out onto different roles, different levels, different partnerships $[\ldots]$ it's thus a question of unpacking what are often stereotyped views held by the student" (SV01).

\subsection{Non-imitative and exploratory learning}

Another closely related topic is that of non-imitative learning: in the experimental placement, students have many more incentives to learn through questioning and reflecting on the placement context and on themselves, as trainees and future social workers. This can help achieve the type of student-centred learning envisaged by the Bologna Process (van Hees, 2010, 42).

Students, supported by supervision, lay out their individual route to their own professionalization: if, on the one hand, the lack of boundaries and the free hand given to them can create anxiety and a sense of confusion, on the other hand, the fact that students must plot their own course through this boundaryless space enables them to find their own bearings. Being alone in a work situation, in fact, spurs the trainees to ponder what professional identity means to them, to think about their strengths and shortcomings in a process of stepping up to the plate and becoming fully engaged.

Though delegated supervision with no on-site practitioners prevents a reassuring mechanism of learning through imitation or contrast from coming into play, it can also stand in the way of the students' maturation and slow the construction of their identity.

As one student remarked, "If the supervisor works in the agency, he tends to give you what he's learned in that setting, while the fact of not having somebody on the inside meant that I had to work out a new role for myself" (S13), while another noted that "[...] the experimental placement helps you a lot in this, because the uncertainty forces you to keep asking yourself what you ought to do, and so you don't fall into the trap of imitating" (S5). 
The interviewed educators pointed out that students in traditional placements tend not infrequently to pattern their identity after that of their supervisor, accepting what they see uncritically. The risk is that the supervisor will be seen as either "absolutely the best, or exactly what they don't want to become" (SV57), as one of the educators stated during the interview. The experimental placement, by contrast, facilitates reflection on the experience, of which the supervisor is a part - without, however, being directly involved in the action.

As regards EPL's ability to innovate and explore non-traditional outlets for the profession, contrasting stances emerged from the students' statements:

- One the one hand, the general level of satisfaction with the lessons learned from the placement shows a number of ups and downs, as some students complain that there was little opportunity to try their hand at the professional tools and "core skills". To assess what they were able to learn from the placement, these students' yardstick is work in the public welfare agencies, which they see as the "real" setting for the profession.

- On the other hand, there was an appreciation for the independence and ability to take the lead that, despite the fears and difficulties, enabled the students to be active participants in the project and to master certain skills that they will be able to rely on throughout their professional careers. This is what one of the young women had to say:

One of the greatest gains I had from the placement was that of knowing how to maintain a professional attitude in highly informal situations where there was a very pronounced risk of slipping into complicit or over-friendly behavior. This placement enriched me in that it helped me understand how to position myself with clients, and today, six years later and with a working career that is now well under way, that specific skill is a fundamental part of my professional baggage (S08).

Students' experiences also paralleled those described in studies of international learning placements, where exposure to a highly unfamiliar setting can cause a sense of disorientation. With good supervision, they can turn this to their advantage in developing an attitude of flexibility and open-mindedness (Askeland et al,, 2016), as reported by an agency contact: "The thing I noticed about these young women is their willingness to call themselves into question, which created a lot of energy, creativity and a desire to expand their horizons to the utmost" (A6). 


\subsection{The impact of experimental placements on the host agencies}

The second research question concerned the role taken by the non-profit sector in the experimental project, and its participation in the practice learning placements. Attention focused on the aspects that led to the decision to host trainees and cooperate with the university. In some cases, interviews with agency contacts indicated a high degree of involvement in terms of professional investment, while there was limited commitment in other cases.

In general, the relationship with the Bachelor of Social Work program was considered to be positive: while there was not always complete agreement with the academics' perspective, there was a willingness to try to find common ground. For most of the interviewees, participating in the experimental project and the flurry of ideas that revolved around the student's experience during the placement created a climate of openness to innovation. An example is provided by one of the first agencies that participated in the project: when the experimental placements started, the agency set out to professionalize its activity, taking a route that culminated in the hiring of six social workers. Interest in making use of practitioners' services also led another agency to employ social workers for the first time. Other agencies understand that having social workers could provide significant added value to their activities, but objective economic difficulties have frustrated their recruitment plans.

Though these data about employing social workers deserve attention, they reflect a modest change in the profession's job market.

These collaborative efforts also had other positive results, including the organizational changes made by the agencies in response to proposals made by trainees. For example, the project contact at one of the cooperatives reported that their team had adopted new professional tools to document patients' social skills and complement the health records they already maintain. In another organization, the trainees' suggestions led to a reorganization of the agency's physical layout to make it more functional and guarantee the clients' privacy.

The relationship with tutors and supervisors also helped build the profession's image, as one agency director explained: "The university was able to make us see how important social workers are" (A8). 
Most of the agency contacts were able to give a picture of the professional skills that the students brought to bear - albeit still somewhat tentatively - during experimental placement. Attention focused on the relational skills and the ability to listen empathetically that the students showed in their interactions with clients. Also mentioned was their capacity for making explicit references to social work's value system, and more specifically to the profession's code of ethics (CNOAS, 2009).

It is interesting to note that the agency contacts considered the trainees to have a more project-oriented approach and an attitude of greater respect for others than the volunteers in the organization. Additional factors that distinguished these trainees from that of people with other educational backgrounds included the ability to look at the overall picture and not focus only on the disease, good problem-solving skills, flexibility and capacity for interprofessional cooperation.

As regards cooperation between the university and the host agencies, the most important achievements can be summarized as follows:

- A number - albeit a small one - of new opportunities for employment were created.

- A channel was opened for communication between agencies and clients who until that time had never considered making use of the skills of a social worker.

- Every major and minor change proposed by the students and introduced in the host agencies' organization can be considered an acknowledgement of the profession's value.

- A lack of cooperation by the agencies sometimes made it impossible to achieve the objectives. Others, however, provided fertile ground for dialog and exchanges of views, with cross-fertilization between different professional cultures.

\section{Concluding discussion}

In summing up, we can say that - as regards the educational potential of the experimental practice-learning project - the statements by tutors and supervisors alike agree in presenting the outcome as highly positive. In the light of these findings, it would appear that these experiences provided the students with two opportunities: that of achieving a close-up understanding (but with guidance and protection in so doing) of what they can expect to encounter in their future careers; and a preview of how the 
skills typical of the profession can be relevant and meaningful in non-traditional settings.

Interprofessional cooperation is another interesting aspect: the students engaged in the project find themselves in close contact with professionals from fields differing from their own. This exchange can provide them with opportunities for integration based on respect for the person as a whole, as well as on an aptitude for working in a team and as part of a network. Obviously, none of this would be feasible without constant reflection on one's own action, where student and supervisor '[...] engage with each other, skirting the pitfalls of competition between professions and selfinvolvement' (Dellavalle, 2011, p. 104).

Given the educational potential indicated by the supervisors and tutors, as well as the investment - financial and otherwise - that the Bachelor of Social Work degree program made in this project, it is only right to ask whether experimental placements can produce effective results, even if the study demonstrated that students' evaluation is not completely satisfactory. Help in framing an answer to this question can be provided by Bruner (1973), whose "learning principles" include two that are relevant here: the first is the "principle of satisfaction", which holds that learning takes place at the moment when one is aware that it can give satisfaction, while the second is the "principle of meaningfulness", i.e., that one learns more effectively if the activities involved are seen as being meaningful. The gap between the EPL's potential and these two principles could be remedied, as the students themselves suggested, by guaranteeing higher visibility and more recognition for the placements.

Being able to provide more visibility for the placement and its achievements could ensure a greater sense of satisfaction with the effort that the experience entailed. Sharing the results with the professional community and recognition from the latter could allay the students' fears of being involved in a niche exercise, instilling them with greater confidence in the course they have taken and the lessons learned from it. It would thus be important to make sure that the valuable material produced by the supervisor and student can become a collective heritage, no longer known only to academics, but extended to the entire professional community.

The project's satisfactory outcomes encourage the degree program to organize further experimental placements with the consequent changes for improving the 
educational experience, though the difficulties expressed by the students and their differing views of the placement's value must be borne in mind.

The firmly rooted idea that the 'public' social worker is the fullest expression of professionalism would appear to confirm that working in the third sector is still regarded as a "minor league" proposition (Scholar, H; McLaughlin, H.; McCaughan, S. \& Coleman, A., 2014; Fazzi, 2012). Consequently, it will be necessary to invest in increasing the role that students have in exploring new situations, and in promoting an attitude of openness to innovation, as well as in overcoming the somewhat stereotyped representations of the profession.

As regards the practice learning process in general, the study's findings highlight the positive impact of organized supervision. This confirms the widespread concern (Ayala et al., 2018) about the limited time available to social workers who supervise traditional placements. Consequently, universities and practitioners' associations should cooperate in implementing policies for supporting supervision at the national as well as the local level, as studies in other countries have also emphasized (Ayala et al., 2018). Such support could profitably be extended to training supervisors in the use of transformative learning models (Askeland et al., 2016).

Delegated supervision proved to be essential, and funding is thus needed so that it can be guaranteed.

To help students achieve new levels of self-understanding and reinforce practice learning, the approach to teaching critical reflection outlined by Theobald, Gardner \& Long (2017) and based on the model proposed by Gardner (2014) could prove useful.

The experimental practice learning project was undoubtedly important in promoting new outlets for the profession and providing social work with many opportunities to come into contact with new and unknown areas, spread its own culture and bring people from other fields closer to its professional core. Though it must be acknowledged that not all of the dealings with the agencies were successful in terms of fostering real cooperation, this is also true of traditional hosts. For this reason, the BSW program will continue with the experimental project, taking greater care in selecting and involving contacts at these agencies. As regards promoting opportunities for social workers in the non-profit, the university could take a leading role in pursuing this aim, working closely together with professional associations and non-profits to develop and implement mutually beneficial strategies. 
A limitation of the study was that it was not able to involve a larger number of the participants in the experimental project. Another limit concerns the time spent to complete the study, due to the lack of research staff dedicated to this project. Nevertheless, the findings still hold true despite the passage of time, as there have been no substantial changes in the situation described herein for the agencies and practice learning arrangements. Indeed, the findings arecurrently being applied in a professional innovation project conducted together with the Regional Association of Social Workers.

\section{Funding}

This research received no specific grant from any funding agency in the public, commercial, or not-for-profit sectors.

\section{Disclosure statement}

No potential conflict of interest was reported by the authors.

\section{Notes on contributors}

Marilena Dellavalle is Assistant Professor of Social Work and Director of Practice Learning at the University of Torino (Italy). She is now a member of the national boards of the Italian Society of Social Work (SocISS) and of Society History of Social Work (SOSTOSS. Her research interests include history and professionalization process of social work, and social work education.

Valentina Rocca is a social worker at a public social service agency UNIONET Settimo Torinese (Italy) 


\section{References}

Ayala, J., Drolet, J., Fulton, A. Hewson, J., Letkemann, L., Baynton,M., Elliott, G., Judge-Stasiak, A., Blaug, C., Gérard Tétreault, A. \& Schweizer, E. (2018). Field education in crisis: experiences of field education coordinators in Canada, Social Work Education, 37(3), pp. 281-293, DOI: 10.1080/02615479.2017.1397109.

Askeland, G. A., Elsa Døhlie, E. \& Grosvold K. (2016). International field placement in social work: Relevant for working in the home country. International Social Work, July 2016, pp. 1-14. DOI: 10.1177/0020872816655200.

Bellinger, A. (2010). Studying the Landscape: Practice Learning for Social Work Reconsidered. Social Work Education, 29 (6), pp. 599-615.

Bertotti, T. (2015). Resources reduction and welfare changes: tensions between social workers and organisations. The Italian case in child protection services. European Journal of Social Work. doi: 10.1080/13691457.2015.1030363

Bogo, M. \& Globerman, J. (1999). Inter-organisational relationships between schools of social work and field agencies: testing a framework for analysis. Journal of Social Work Education, 35 (2), 265-274.

Bruner, J. S. (1973). Beyond the information given: Studies in the psychology of knowing. Oxford, UK: W. W. Norton.

Clapton, G.; Cree, V., Allan, M., Edwards R., Ruth Forbes R.; Irwin, M.; Paterson, W. \& Richard Perry (2006). Grasping the Nettle: Integrating Learning and Practice Revisited and Re-imagined. Social Work Education, 25(6), 645-656. doi: 10.1080/02615470600833634

CNOAS - Consiglio Nazionale Ordine Assistenti Sociali (2009). Codice deontologico dell'assistente sociale, Roma.

CNR - Consiglio Nazionale della Ricerca. Commissione per l'Etica della Ricerca e la Bioetica (2015). Linee guida per l'integrità nella ricerca. To link to this article:

https:/www.cnr.it/sites/default/files/public/media/doc_istituzionali/linee-guidaintegrita-nella-ricerca-cnr-commissione etica.pdf? $\mathrm{v}=1$

Crisp, B.R \& Hosken, N. (2016). A fundamental rethink of practice learning in social work education. Social Work Education, 35 (5), 506-517. doi: $10.1080 / 02615479.2016 .1175422$

Dellavalle, M. (2014). La interdisciplinariedad y la relación teoría/práctica: una experiencia interdepartamental. Azarbe. Revista Internacional de Trabajo Social y Bienestar, 3, 15-20. To link to this article: http://revistas.um.es/azarbe/article/view/198311/161581

Dellavalle, M. (2011). Il tirocinio nella formazione al servizio sociale. Un modello di apprendimento dall'esperienza. Roma: Carocci.

Dewey, J. (1910). How we think. Lexington, Mass: D.C. Heath.

Domakin, A. (2015). The Importance of Practice Learning in Social Work: Do We Practice What We Preach? Social Work Education, 34 (4), 399-413, doi: 10.1080/02615479.2015.1026251.

Dominelli, L. (1996). Deprofessionalizing Social Work: Anti-Oppressive Practice, Competencies and Postmodernism. British Journal of Social Work (1996) 26 (2): 153-175.

Facchini, C. (Ed.) (2010). Tra impegno e professione. Gli assistenti sociali come soggetto del welfare. Bologna: Il Mulino. 
Fargion, S. (2008). Reflections on Social Work's Identity. International Themes in Italian Practitioners' Representation of Social Work. International Social Work, 51 (2), 206-219. doi: 10.1177/0020872807085859

Fazzi, L. (2012). Social work in the public and non-profit sectors in Italy: What are the differences? European Journal of Social Work, 15 (5), 629-644, doi: 10.1080/13691457.2011.557180.

Fazzi, L. \& Rosignoli, A. (2014). Reversing the Perspective: When the Supervisors Learn from Their Trainees. British Journal of Social Work, 46 (1), 1-18. doi: 10.1093/bjsw/bcu112

Gardner, F. (2014). Being critically reflective. Basingstoke, UK: Palgrave MacMillan.

Garrett, P. M. \& Bertotti, T. F. (2016). Social work and the politics of 'austerity': Ireland and Italy. European Journal of Social Work. doi: 10.1080/13691457.2016.1185698.

Gursansky, D., \& Le Seur, E. (2012). Conceptualising field education in the twenty-first century: Contradictions, challenges and opportunities. Social Work Education, 31(7), 914-931. doi: 0.1080/02615479.2011.595784

Hubbard, R. Kitchin, G. (2010). Valuing Freelancers: Supporting Off Site Practice Assessors to Provide Quality Practice Learning. Social Work Education: The International Journal, 29 (5), 503-522.

Lewis, L.A., Kusmaul, N., Elze, D. \& Butler, L. (2016). The Role of Field Education in a University-Community Partnership Aimed at Curriculum Transformation. Journal of Social Work Education, 52 (2), 186-197.

Man Lam, Wong \& Tse Fong Leung (2007). An Unfinished Reflexive Journey: Social Work Students' Reflection on their Placement Experiences. British Journal of Social Work (2007) 37 (1), pp. 91-105. doi:10.1093/bjsw/bcl320

Marlowe, J., Appleton, C., Chinnery, S-A. \& Van Stratum, S. (2015). The Integration of Personal and Professional Selves: Developing Students' Critical Awareness in Social Work Practice, Social Work Education. 34 (1), 60-73, DOI: 10.1080/02615479.2014.94923.

Mezirow, J. (1991). Transformative Dimensions of Adult Learning. San Francisco: Jossey-Bass.

Morley, C. \& Dunstan, J. (2013). Critical Reflection: A Response to Neoliberal Challenges to Field Education?. Social Work Education. 32 (2), 141-156, DOI: 10.1080/02615479.2012.730141.

Noble, C, (2001). Researching Field Practice in Social Work Education. Integration of Theory and Practice through the Use of Narratives. Journal of Social Work, 1 (3), 347-360. doi: 10.1177/146801730100100307.

Rehn, M. \& Kalman, H. (2016). Social work students' reflections on challenges during field education, Journal of Social Work, June 12, 1-17, doi: $10.1177 / 1468017316654362$.

Scholar, H; McLaughlin, H.; McCaughan, S. \& Coleman, A. (2014). Learning to Be a Social Worker in a Non-traditional Placement: Critical Reflections on Social Work, Professional Identity and Social Work Education in England. Social Work Education, Vol. 33, No. 8, 998-1016. doi: 10.1080/02615479.2014.926320.

Schön D.A. (1993). The Reflexive Practitioner. New York: Basic Books, Inc.

Sicora, A. (2010). Errore e apprendimento nelle professioni di aiuto. Santarcangelo di Romagna (RN): Maggioli.

Theobald, J., Gardner, F. \& Long, N. (2017). Teaching Critical Reflection in Social Work Field Education. Journal of Social Work Education, 53:2, 300-311, DOI:10.1080/10437797.2016.1266978. 
Tognetti Bordogna, M. (ed.) (2015). Voglio fare l'assistente sociale. Milano: FrancoAngeli.

van Hees, G. (2010). Student Supervision in the Bachelor of Social Work in Europe, a Comparison. In van Hees \& Geißler-Piltz (Eds). Supervision meets Education. Maastricht: CESRT, pp. 41-77.

Wibeck,V.\& Abrandt D. Öberg. G. (2007). Learning in focus groups: an analytical dimension for enhancing focus group research. Qualitative Research, 2, 249-267 DOI: $10.1177 / 1468794107076023$.

Wilson, G. (2014). Building partnerships in social work education: Towards achieving collaborative advantage for employers and universities. Journal of Social Work, 14 (1), 3-22. doi: 10.1177/1468017313475547.

Wilson, G. \& Kelly, B. (2010). Evaluating the Effectiveness of Social Work Education: Preparing Students for Practice Learning. British Journal Social Work, 40 (8), 24312449. doi: 10.1093/bjsw/bcq019. 